\title{
Markets and linguistic diversity
}

\author{
Ramon Caminal, professor investigador a l'Institut d'Anàlisi Econòmica (CSIC) \\ $i$ Research Fellow del Center for Economic Policy Research (CEPR)
}

\begin{abstract}
The choice of language is a crucial decision for firms competing in cultural goods and media markets with a bilingual or multilingual consumer base. Insofar as multilingual consumers have preferences regarding the intrinsic characteristics (content) as well as the language of the product, we can examine the efficiency of market outcomes in terms of linguistic diversity. In this paper, I extend the spokes model and introduce language as an additional dimension of product differentiation. I show that: (i) if firms supply their product in a single language (the adoption model), then the degree of linguistic diversity is inefficiently low and (ii) if some firms supply more than one linguistic version (the translation model), then in principle the market outcome may exhibit insufficient or excessive linguistic diversity. However, excessive diversity is associated with markets where the share of products in the minority language is disproportionately high with respect to the relative size of the linguistic minority.
\end{abstract}

\section{Resum}

Escollir una llengua és una decisió crucial per a empreses que competeixen en béns culturals i mercats amb una o més llengües de consum. En aquesta conferència s'examina l'eficiència dels resultats del mercat pel que fa a la diversitat lingüística. En aquest article es fa una extensió del model de parla i s'introdueix la llengua com una dimensió addicional de diferenciació del producte. Es demostra que si les empreses ofereixen els seus productes en una única llengua, llavors el grau de diversitat lingüistica és ineficient i baix; si algunes empreses ofereixen més d'una llengua, llavors en el mercat principal els resultats poden mostrar insuficiències o una diversitat lingüística excessiva. No obstant això, una excessiva diversitat està associada amb els mercats on la fracció de productes en la llengua minoritària és desproporcionadament alta respecte a la grandària relativa de la minoria lingüística.

Producers of cultural goods (like books and films) and media products (newspapers, TV and radio) can only make their specific content available to their audiences and readerships through a particular language. The choice of language is a trivial decision if consumers are monolingual. However, in many local markets, as well as in the global market, a substantial proportion of consumers are competent in more than one language. It is precisely the presence of multilingual consumers that makes language selection a difficult decision for firms and a sensitive issue for the general public. Let us first discuss this topic in the context of the global market. It is well known that the spread of English as a second language has accelerated over the last decades. Some commentators have expressed their concern about the potential negative effect of this expansion on the presence and discussion of other languages. For now the signs are weak but significant. For instance, US and UK-based TV stations specialized in international news are attracting larger audi- 
ences around the world. At the same time stations based in non-English speaking countries have set up English channels (Al Jazeera, Russia Today, France). Films and books originally in English already enjoy a clearly dominant position in world markets although they are typically translated or dubbed into local languages. However, incentives to meet the costs of translation and dubbing may be significantly reduced as consumers' competence in English improves.

Clearly both the expansion of English as a second language and the integration of cultural goods and media markets are likely to speed up in the coming years and will probably bring very substantial benefits. However, they may also involve significant costs and market failures that need to be considered. In particular, a reduction in the degree of linguistic diversity may specifically harm monolingual social groups; but, more generally, it may negatively affect those consumers whose mother tongue is not English and have a preference for consuming these products in a different language. Moreover, it's crucial for a particular language to be present in the media and cultural goods markets to ensure its vitality and prestige, potentially influencing its medium and long-term dynamics.

Geographical areas where the majority of the population is bilingual can provide useful insights into the long-term implications of the spread of English. Take the example of Catalonia. A very large proportion of the 7 million inhabitants can speak and read the two main languages: Catalan and Spanish (Castilian). Surveys conducted over the last twenty years indicate that Spanish is the family language for roughly half the population, while Catalan is for the other half (data on the daily use of the two languages also show approximately the same fifty-fifty pattern.) One could naively expect that one half of consumption of cultural goods and media products in Catalonia would be in Catalan and the other half in Spanish. But this is not the case, especially if we focus on non-subsidized, privately provided goods and services. More specifically, 24\% of the TV audience consumes programmes in Catalan but only a tiny fraction is broadcast by private stations. Similarly, $43 \%$ of the radio audiences correspond to programmes in Catalan but the proportion supplied by private radio stations is also small. Private supply in Catalan is higher in the newspaper and book markets. About 22\% of newspapers and $20 \%$ of books (excluding textbooks) consumed in Catalonia are in Catalan. Finally, the consumption of films dubbed into Catalan or originally produced in this language is close to zero (subtitles are rarely used in Spain). It is important to emphasize that only a few extra million consumers outside Catalonia speak or read Catalan while, in most of these examples, the relevant market is either Spain (46 million, all competent in Spanish) or the world's Spanish-speaking population (approximately 400 million).

These indicators can be interpreted in different ways. Nevertheless, the low private supply of products in Catalan, combined with wide political support for the public financing of TV and radio stations that broadcast programmes exclusively in Catalan, suggest that market outcomes might be biased against minority languages.

As suggested above, the relationship between linguistic preferences and market outcomes is dynamic with causality running in both directions. This paper contributes to our understanding of these issues by focusing on the causality from preference to outcome. In particular, I ask whether markets tend to provide too little linguistic diversity for a given distribution of linguistic preferences. I therefore analyze a static model of product variety where consumers have preferences re- 
garding the intrinsic characteristics (content) as well as the language of the product. The model is agnostic about the origin of linguistic tastes. A preference for a particular language may simply indicate rejection for greater proficiency or a desire to learn the language. It could also emerge from ideological or even aesthetic reasons. Consumers belong to different linguistic communities of unequal size. These communities are not completely segmented insofar as members of the minority are bilingual while the majority members may be bilingual (symmetric bilingualism) or monolingual (asymmetric bilingualism). Bilingual consumers are not indifferent about the language of the product; strictly speaking, they prefer to consume products in one of the languages (such as their mother tongue) although they may be willing to consume products in their second language depending on availability, content preferences and price differentials.

The model extends the spokes model (Chen and Riordan, 2007) by adding an additional dimension of product differentiation (language). Thus consumers may give up a good match in terms of content for a better linguistic match. In fact, one key parameter of the model is the degree of linguistic substitutability of content. It is very convenient to start by assuming that each variety (defined by its content) must be supplied in a single language (the adoption model). Next, the analysis is extended by allowing firms to provide more than one linguistic version of each variety (the translation model). In the real world, translations are not restricted to books and films but nowadays are relatively present in most segments of cultural goods and media markets.

The main results of the paper are the following. Firstly, in the adoption model, market forces are biased against minority languages; i.e. all things being equal, the proportion of varieties supplied in the minority language, in equilibrium, is below the level that maximizes the total surplus (the level of linguistic diversity is inefficiently low). Let us consider the social planner's problem. If the degree of linguistic substitutability is not too high (with respect to the size of the minority community), then it is efficient to supply a positive proportion of varieties in the minority language since a number of consumers can be assigned to products on the basis of their linguistic preferences, which more than compensates the content mismatch. In fact, as the degree of linguistic substitutability falls (i.e. the intensity of linguistic preferences increases), or as the size of the minority community increases, then the optimal proportion of varieties in the minority language increases. However, private incentives to supply goods in the minority language are smaller than social incentives. The main driving force behind this is the size of the consumer base. Actually, this is the only force in a regulated environment where prices are fixed exogenously (and independently of the product's language). In this case, no firm would ever find it profitable to supply its product in the minority language since that would imply lower sales. In an unregulated environment, however, some firms may be willing to specialize, adopt the minority language and take advantage of the higher willingness to pay of members of the minority linguistic community. However, a firm that switches to the minority language is unable to capture all the surplus generated.

The second main result concerns the translation model. In this case, the market outcome may exhibit insufficient or excessive linguistic diversity. However, unlike most models of product differentiation, whether there is too much or too little diversity can be associated with the value of observable variables. Specifically, too much diversity only arises in markets where the cost of translation is so low that the share of products in the minority language is disproportionately high with respect to the relative size of the linguistic minority. In order to understand this result it is 
important to note, that in the extreme symmetric case where both linguistic communities are of the same size, despite the fact that the level of linguistic diversity is always efficient, the market allocation is inefficient because firms tend to generate too many translations. The reason is that most consumers attracted by a second linguistic version of a particular variety come from rival firms (business stealing effect). Thus, back in the asymmetric case, the ambiguous result is a combination of the forces described in the adoption model and the excessive incentives to translate. Specifically, if the cost of translation is relatively high, then we are very close to the adoption model. On the other hand, if the cost of translation is sufficiently low then, in equilibrium, most firms offer a second linguistic version in order to steal consumers from rival firms.

Summarizing, the adoption model formalizes the widespread perception that market forces tend to work against minority languages. However, the efficiency of market outcomes is likely to improve as the application of new technologies reduces the costs of translations. If this cost reduction is sufficiently drastic, then the direction of this inefficiency may even be reversed.

There is growing literature on the economics of language which has examined a broad range of issues, such as second language acquisition (Selten and Pool, 1991; Church and King, 1993 and Lazear, 1999), the intergenerational transmission of mother tongues (John and Yi, 2001), the role of language in foreign trade (Melitz, 2007b), the choice of official languages in multilingual societies (Ginsburgh et al., 2005) and the relationship between language policy and human capital accumulation (Ortega and Tangeras, 2008). To the best of my knowledge, the issue of language adoption in cultural goods and media markets has not yet been the subject of formal economic analysis.

\section{References}

Caminal, R. and Granero, Ll. (2008). Multi-Product Firms and Product Variety. Mimeo.

Chen, Y. and Riordan, M. (2007). "Price and Variety in the Spokes Model". The Economic Journal, 117 (522): 897-921.

CHurch, J. and KING, I. (1993). "Bilingualism and Network Externalities". Canadian Journal of Economics, 36 (2): 337-345.

Dixit, A. and Stiglitz, J. (1997). "Monopolistic Competition and Optimum Product Diversity". American Economic Review, 67 (3): 297-308.

Ginsburgh, V., Ortuño-Ortín, I. and Weber, S. (2005). "Disenfranchisement in Linguistically Diverse Societies: The Case of the European Union". Journal of the European Economic Association, 3 (4): 946-965.

Ginsburgh, V., Weber, S. and Weyers, S. (2007). Economics of Literary Translation. A Simple Theory and Evidence. CEPR Discussion Paper 6432.

Graddol, D. (2006). English Next. British Council. http:/www.britishcouncil.org/learning -research-english-next.pdf.

John, A. and Yi, K.-M. (2001). Language and Location. Mimeo.

LAZEAR, E. (1999). “Culture and Language”. Journal of Political Economy, 107 (6): 95-126.

Mankiw, G. and Whinston, M. (1986) "Free Entry and Social Inefficiency". Rand Journal of Economics, 17 (1): 48-58. 
Melitz, J. (2007a). "The Impact of English Dominance on Literature and Welfare". Journal of Economic Behavior and Organization, 64: 193-215.

— (2007b). "Language and Foreign Trade". European Economic Review, 52 (4): 667-699.

Ortega, J. and TANGERAS, T. (2008). "Unilingual Versus Bilingual Education System: A Political Economy Analysis". Journal of the European Economic Associationi, 6 (5): 1078-1108.

Peitz, M. and Valletti, T. (2008). "Content and Advertising in the Media: Pay-TV versus Freeto-Air". International Journal of Industrial Organization, 26 (4): 949-965.

SALOP, S. (1979). "Monopolistic Competition with Outside Goods". The Bell Journal of Economics, 10 (1): 141-156.

Selten, R. and Pool, J. (1991). "The Distribution of Foreign Language Skills as a Game Equilibrium". In: Game Equilibrium Models. Edited by R. Selten. Vol. IV, Social and Political Interaction. Berlin: Springer-Verlag: 64-87. 